\title{
Gestational Diabetes Mellitus and Developmental Programming
}

\author{
Anne H.Y. Chu ${ }^{a}$ Keith M. Godfrey ${ }^{b}$
}

aSingapore Institute for Clinical Sciences (SICS), Agency for Science, Technology and Research (A*STAR), Singapore, Singapore; bMRC Lifecourse Epidemiology Unit and NIHR Southampton Biomedical Research Centre, University of Southampton and University Hospital Southampton NHS Foundation Trust, Southampton, UK

\section{Key Messages}

- A mother's glycaemic status and weight during before conception and pregnancy influence the long-term health of the offspring.

- The offspring's future health can be programmed through the role of epigenetic changes induced by a hyperglycaemic environment in utero.

- More longitudinal studies are warranted to investigate the causality and underlying mechanisms of GDM on offspring's longterm health to provide a basis for developing effective interventions during this critical period, with the aim of improving lifelong health and wellbeing.

\section{Keywords}

Developmental origins of health and disease - Epigenetics . Gestational diabetes · Life course epidemiology

Non-communicable disease

\begin{abstract}
During normal pregnancy, increased insulin resistance acts as an adaptation to enhance materno-foetal nutrient transfer and meet the nutritional needs of the developing foetus, particularly in relation to glucose requirements. However, about 1 in 6 pregnancies worldwide is affected by the inability of the
\end{abstract}

mother's metabolism to maintain normoglycaemia, with the combination of insulin resistance and insufficient insulin secretion resulting in gestational diabetes mellitus (GDM). A growing body of epidemiologic work demonstrates longterm implications for adverse offspring health resulting from exposure to GDM in utero. The effect of GDM on offspring obesity and cardiometabolic health may be partly influenced by maternal obesity; this suggests that improving glucose and weight control during early pregnancy, or better still before conception, has the potential to lessen the risk to the offspring. The consequences of GDM for microbiome modification in the offspring and the impact upon offspring immune dysregulation are actively developing research areas. Some studies have suggested that GDM impacts offspring neurodevelopmental and cognitive outcomes; confirmatory studies will need to separate the effect of GDM exposure from the complex interplay of social and environmental factors. Animal and human studies have demonstrated the role of epigenetic modifications in underpinning the predisposition to adverse health in offspring exposed to suboptimal hyperglycaemic in utero environment. To date, several epigenomewide association studies in human have extended our knowledge on linking maternal diabetes-related DNA methylation marks with childhood adiposity-related outcomes. Identification of such epigenetic marks can help guide future research to develop candidate diagnostic biomarkers and pre- karger@karger.com

www.karger.com/anm

() 2021 S. Karger AG, Basel

\section{Karger ${ }^{\prime \prime}=$}

Keith M. Godfrey

NIHR Southampton Biomedical Research Centre

University of Southampton and University Hospital Southampton NHS Foundation Trust Mailpoint 95, Southampton SO16 6YD (UK)

kmg @ mrc.soton.ac.uk 
ventive or therapeutic strategies. Longer-term interventions and longitudinal studies will be needed to better understand the causality, underlying mechanisms, or impact of GDM treatments to optimize the health of future generations.

(C) 2021 S. Karger AG, Basel

\section{Introduction}

Gestational diabetes mellitus (GDM) is a glucose tolerance disorder with onset during pregnancy [1]. GDM has been estimated to affect $14.4 \%$ of pregnancies globally, ranging from $7.5 \%$ in the Middle East and North Africa region to $27.0 \%$ in the South-East Asia region [2]. Although dysglycaemia usually improves after delivery, untreated GDM increases the risk of short-term complications including foetal overgrowth, shoulder dystocia, caesarean delivery, and hypertensive disorders [3]. In the long term, exposure to GDM will likely predispose both the mother and her child to non-communicable diseases (NCDs) later in life.

NCDs are often seen as diseases of adult lifestyle and are an important public health issue. Their aetiology is likely multifactorial, involving interactions between environmental and genetic factors and multiple risk pathways. Substantial evidence now suggests that NCDs partly originate through environmental exposures before and during pregnancy [4], which have lasting effects on the developing foetus and serve as potential targets in reversing the epidemic of NCDs. It has become apparent that children born to mothers with GDM have an increased lifetime risk for metabolic diseases compared with unexposed children [5]. This concept of lasting consequences of early-life nutrition for later disease risk is widely termed "developmental programming" (Fig. 1).
There is increasing epidemiological evidence linking the early-life environmental exposures (i.e., maternal malnutrition/overnutrition, environmental chemicals, and stress) with later-life health outcomes - conceptualized as the "developmental origins of health and disease" (DOHaD). Compelling studies from animal models have provided strong evidence in support of the DOHaD concept. These have, for example, shown that in utero exposure to maternal diabetes and/or obesity disrupts the development and function of the hypothalamus, predisposing offspring to obesity [6, 7]. Several decades ago, Pedersen [8] proposed that foetal adipogenesis can result from foetal hyperinsulinemia induced by maternal hyperglycaemia, with more recent evidence suggesting that the mechanisms involved in lasting effects on obesity risk include epigenetic changes [9]. In this review, we highlight some of the latest findings on the long-term health consequences in offspring born to mothers with GDM, specifically relating to body composition and cardiometabolic health, allergic diseases, immune dysregulation/infections, and neurobehavioral outcomes and elaborate the epigenetic changes as one of the major mechanisms linking GDM with long-term "programmed" adverse effects on the offspring.

\section{Offspring Body Composition and Cardiometabolic Health}

While GDM has been linked with a higher offspring body mass index (BMI), several studies have suggested that this association is confounded by higher BMI in the mother. Table 1 summarizes selected studies that have examined the association of GDM with offspring body composition and cardiometabolic health. In the Hyperglycaemia and Adverse Pregnancy
Fig. 1. Gestational diabetes mellitus and developmental programming.

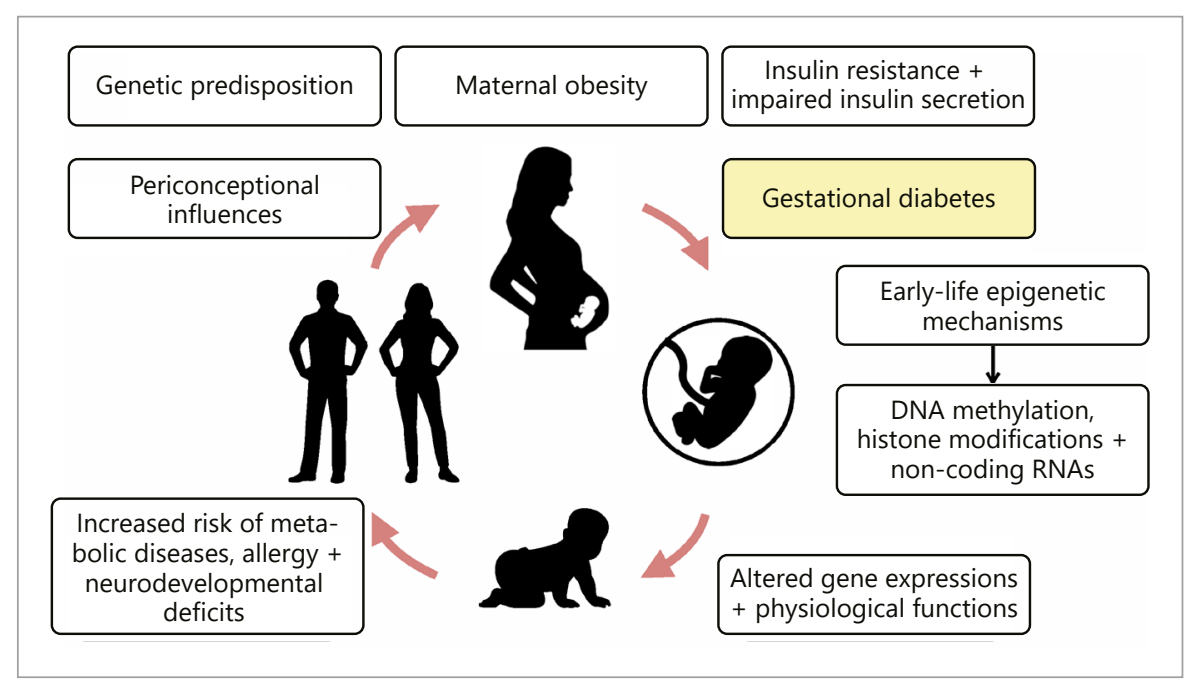


Table 1. Selected studies linking GDM with offspring body composition and cardiometabolic health

\begin{tabular}{|c|c|c|c|c|c|c|}
\hline \multicolumn{7}{|c|}{ Body composition } \\
\hline $\begin{array}{l}\text { Lowe } \\
\text { et al. [10], } \\
\text { USA }\end{array}$ & Cohort & $\begin{array}{l}\text { Hyperglycaemia and } \\
\text { Adverse Pregnancy } \\
\text { Outcome (HAPO) study }\end{array}$ & 4,832 & $\begin{array}{l}\text { International Association of } \\
\text { Diabetes and Pregnancy } \\
\text { Study Groups (IADPSG) }\end{array}$ & $\begin{array}{l}\text { Mean (SD): } \\
11.4(1.2)\end{array}$ & $\begin{array}{l}\text { Not associated with overweight/obesity } \\
\text { (OR: } 1.21,95 \% \mathrm{Cl}: 1.00-1.46) \text {, adjusted } \\
\text { for maternal BMI at OGTT during } \\
\text { pregnancy }\end{array}$ \\
\hline $\begin{array}{l}\text { Kawasaki } \\
\text { et al. [12], } \\
\text { Japan }\end{array}$ & $\begin{array}{l}\text { Meta- } \\
\text { analysis }\end{array}$ & $\begin{array}{l}\text { Included } 4 \text { cohort studies } \\
\text { adjusting for maternal BMI; } \\
\text { Denmark, Hong Kong SAR, } \\
\text { USA }\end{array}$ & 890 & $\begin{array}{l}\text { Self-report, questionnaire, } \\
\text { WHO criteria 1999, OGTT }\end{array}$ & Range: $7-20$ & $\begin{array}{l}\text { Associated with } 2-\mathrm{h} \text { plasma glucose } \\
\text { (pooled } \mathrm{MD}: 0.43 \mathrm{mmol} / \mathrm{L}, 95 \% \mathrm{Cl} \text { : } \\
0.18-0.69 \text { ), adjusted for maternal } \\
\text { pre-pregnancy BMI }\end{array}$ \\
\hline $\begin{array}{l}\text { Lowe } \\
\text { et al. [21], } \\
\text { USA }\end{array}$ & Cohort & $\begin{array}{l}\text { HAPO Follow-up Study } \\
\text { (FUS) }\end{array}$ & 4,160 & $\begin{array}{l}\text { International Association of } \\
\text { Diabetes and Pregnancy } \\
\text { Study Groups (IADPSG) }\end{array}$ & $\begin{array}{l}\text { Mean (SD): } \\
\text { 11.4 (1.2) } \\
\text { Range: } 10-14\end{array}$ & $\begin{array}{l}\text { Associated with IGT (OR: } 1.96,1.41- \\
2.73 \text { ), insulin sensitivity (adjusted MD: } \\
-76.3,-130.3 \text { to }-22.4 \text { ) and oral } \\
\text { disposition index (adjusted MD: }-0.12 \text {, } \\
-0.17 \text { to }-0.064 \text { ), adjusted for family } \\
\text { history of diabetes, maternal BMI, and } \\
\text { child BMI z-score } \\
\text { Not associated with IFG (OR: } 1.09,95 \% \\
\text { Cl: } 0.78-1.52 \text { ) }\end{array}$ \\
\hline \multicolumn{7}{|c|}{ Cardiovascular outcomes } \\
\hline $\begin{array}{l}\text { Øyen } \\
\text { et al. [23], } \\
\text { Denmark }\end{array}$ & Cohort & $\begin{array}{l}\text { Data linkage of Denmark's } \\
\text { nationwide registers }\end{array}$ & $2,025,727$ & Medical record & $\begin{array}{l}\text { From birth } \\
\text { to } 34\end{array}$ & $\begin{array}{l}\text { GDM in third trimester associated with } \\
\text { any type of congenital heart defects } \\
\text { (adjusted relative risk: } 1.36,95 \% \mathrm{Cl} \text { : } \\
1.07-1.69 \text { ) } \\
\text { No association for GDM in second } \\
\text { trimester }\end{array}$ \\
\hline $\begin{array}{l}\text { Yu } \\
\text { et al. [22], } \\
\text { Denmark }\end{array}$ & Cohort & $\begin{array}{l}\text { Danish national health } \\
\text { registries }\end{array}$ & 26,272 & Medical record & $\begin{array}{l}\text { From birth } \\
\text { to } 40\end{array}$ & $\begin{array}{l}\text { Associated with overall CVD (HR: } 1.19 \text {, } \\
95 \% \mathrm{Cl}: 1.07-1.32) \text {, hypertensive } \\
\text { disease (HR 1.77, 1.27-2.48), adjusted } \\
\text { for sociodemographic status and } \\
\text { maternal/paternal history of CVD }\end{array}$ \\
\hline
\end{tabular}

$\mathrm{Cl}$, confidence interval; CVD, cardiovascular disease; GDM, gestational diabetes mellitus; HR, hazard ratio; MD, mean difference; IFG, impaired fasting glucose; IGT, impaired glucose tolerance; NDDG, National Diabetes Data Group; OGTT, oral glucose tolerance test; OR, odds ratio; SD, standard deviation; WHO, World Health Organization. 
Outcomes (HAPO) follow-up study of children aged 10-14 years, no association was found between GDM and overweight/obesity defined by BMI after adjusting for maternal BMI during pregnancy [10]. Similarly, a recent populationbased retrospective study of 33,157 children aged 1-6 years showed that the significant associations of GDM coupled with large-for-gestational age on childhood overweight were no longer apparent after adjusting for pre-pregnancy BMI [11]. These findings are consistent with those of a meta-analysis [12], suggesting that GDM was not associated with BMI zscores when accounting for maternal pre-pregnancy BMI, but few studies have accounted for maternal treatment for GDM as a moderating influence [13]. Higher maternal BMI could be associated with higher childhood adiposity through genetic transmission, shared postnatal lifestyle/environment, and intrauterine environment [14]. Alternatively, since BMI does not distinguish the contributions of fat and lean mass, using direct measures of child adiposity (based on skinfold or simple imaging measurements) could be feasible options in epidemiological studies [10, 15, 16]. Positive associations between GDM and skinfold thickness have been observed in children at birth and later childhood (aged 5-10 years), with limited evidence in children aged $2-5$ years [17].

Evidence for an effect of GDM on offspring abnormal glucose tolerance is mixed as data from several meta-analyses have provided somewhat inconsistent findings. Positive associations between GDM and postnatal abnormal glucose metabolism (fasting plasma glucose, post-prandial, and diabetes mellitus) in the offspring were reported in a systematic review of prospective cohort studies [18]. In a meta-analysis including 11 studies, marginally higher fasting plasma glucose levels were found in offspring exposed to GDM compared with those who were not (standard mean difference: $0.43,95 \%$

The effect of GDM on offspring obesity and cardiometabolic health may be in part influenced by maternal obesity was independent of maternal pre-pregnancy BMI. Similarly, GDM was associated with higher risk of impaired glucose tolerance (based on 30-min, 1-h, and 2-h plasma glucose) but not impaired fasting glucose in 4,160 children from the HAPO follow-up study [21].

The observed discrepancies in the relation of GDM with impaired glucose tolerance and impaired fasting glucose may result from distinct pathophysiology induced by in utero exposure to GDM, in which skeletal muscle function (implicated in the insulin resistance of impaired glucose tolerance), not the liver, may be more vulnerable to GDM. Also, the HAPO follow-up study found that GDM was associated with lower child insulin sensitivity (Matsuda index) and $\beta$-cell compensation for insulin resistance (disposition index) [10]. These associations were independent of maternal BMI during pregnancy and child's BMI z-score, reinforcing the hypothesis that intrauterine exposure to hyperglycaemia plays a part in glucose intolerance among offspring. Foetal $\beta$-cell insulin dysfunction, arising from intrauterine hyperglycaemia and manifesting as a decline in $\beta$-cell compensation, is likely to contribute to a progressively increasing metabolic load and an increased risk of impaired glucose tolerance in children of mothers with GDM. This does not preclude the possibility that the above associations could be partly due to some overlap in genetic susceptibility to GDM and type 2 diabetes, given that insulin resistance and/or insulin secretory defects are key players in the pathogenesis of these conditions.

To date there are relatively few studies on the association between GDM and cardiovascular morbidity. Nonetheless, a recent 40-year follow-up study of the Danish population-based cohort found an increased rate of early-onset cardiovascular disease (HR: 1.19, 95\% Cl: 1.071.32) and hypertensive disease (HR 1.77, 95\% Cl: 1.27-2.48) in offspring of mothers with GDM [22]. These associations were inconfidence interval $[\mathrm{Cl}]$ : $0.08-$

$0.77,6,423$ children) [19]. Likewise, in a retrospective matched cohort study of Canadian mother-offspring pairs, incident diabetes in offspring from birth to 22 years was higher in those born to mothers with GDM (hazard ratio [HR]: 1.77, 95\% Cl: 1.41-2.22) [20]. However, the aforementioned studies did not account for a potential confounding effect of maternal BMI. In contrast, an earlier meta-analysis showed no association of GDM with childhood diabetes or fasting plasma glucose but a higher level of 2-h plasma glucose from prepubertal to early adulthood (pooled mean difference: 0.43 $\mathrm{mmol} / \mathrm{L}, 95 \% \mathrm{Cl}: 0.18-0.69,890$ children) [12]. This finding dependent of sociodemographic status and maternal/paternal history of cardiovascular disease. A 34-year follow-up of the Danish cohort with over 2 million births reported a modest increase in risk of specific congenital heart defects in offspring born to mothers with GDM compared with mothers with pre-gestational diabetes [23]. Interestingly, a systematic review suggested that the association between GDM and congenital heart defects was evident only in women who had both GDM and pre-pregnancy obesity [24]. The effect of GDM on offspring obesity and cardiometabolic health may be in part influenced by maternal obesity; this has led to the notion 
Table 2. Selected studies linking GDM with offspring allergy

\begin{tabular}{|c|c|c|c|c|c|c|}
\hline Study & Design & Cohort & $\begin{array}{l}\text { Sample } \\
\text { size }\end{array}$ & GDM criteria & $\begin{array}{l}\text { Offspring } \\
\text { age, years }\end{array}$ & Major outcomes for GDM-exposed offspring \\
\hline $\begin{array}{l}\text { Kumar } \\
\text { et al. [26], } \\
\text { USA }\end{array}$ & Cohort & Boston birth cohort & 680 & $\begin{array}{l}\text { Medical } \\
\text { record }\end{array}$ & $\begin{array}{l}\text { Mean (SD): } \\
3.2(2.3)\end{array}$ & $\begin{array}{l}\text { In term births, GDM associated with atopic } \\
\text { dermatitis (OR: } 7.2,95 \% \mathrm{Cl}: 1.5-34.5) \text {, allergen } \\
\text { sensitization }(5.7,1.2-28.0) \text {, food sensitization (8.3, } \\
1.6-43.3 \text { ) }\end{array}$ \\
\hline $\begin{array}{l}\text { Martinez } \\
\text { et al. [25], } \\
\text { USA }\end{array}$ & Cohort & $\begin{array}{l}\text { Kaiser Permanente Southern California } \\
\text { hospitals (retrospective birth cohort) }\end{array}$ & 97,554 & $\begin{array}{l}\text { Carpenter- } \\
\text { Coustan }\end{array}$ & $\begin{array}{l}\text { Median age: } \\
7.6\end{array}$ & $\begin{array}{l}\text { GDM requiring antidiabetic medications associated } \\
\text { with childhood asthma (HR: } 1.12,95 \% \mathrm{Cl}: 1.01-1.25) \text {, } \\
\text { adjusted for maternal asthma }\end{array}$ \\
\hline $\begin{array}{l}\text { Zugna } \\
\text { et al. [27], } \\
\text { Italy }\end{array}$ & $\begin{array}{l}\text { Meta- } \\
\text { analysis }\end{array}$ & $\begin{array}{l}\text { Eleven European birth cohorts } \\
\text { participating in the CHICOS (developing } \\
\text { a child cohort research strategy for } \\
\text { Europe) project }\end{array}$ & 85,509 & $\begin{array}{l}\text { Exposure: } \\
\text { maternal } \\
\text { diabetes }\end{array}$ & $\begin{array}{l}\text { From birth to } \\
1-2\end{array}$ & $\begin{array}{l}\text { Maternal diabetes (regardless of type) associated } \\
\text { with ever wheezing (pooled RR: } 1.02,95 \% \mathrm{Cl} \text { : } 0.98- \\
1.06) \text { and recurrent wheezing }(1.24,0.86-1.79)\end{array}$ \\
\hline
\end{tabular}

$\mathrm{Cl}$, confidence interval; GDM, gestational diabetes mellitus; HR, hazard ratio; SMD, standardized mean difference; RR, risk ratio.

that improving glycaemia and weight control during early gestation, or better still before conceiving, has the potential to lessen the risk.

\section{Offspring Allergic Diseases}

Children born to mothers with GDM may be at risk of immune dysregulation. Table 2 summarizes selected studies that have examined the association of GDM and offspring allergy. A recent US study of 97,554 children (median age: 7.6 years) reported evidence that the rate of childhood asthma might be influenced by more severe GDM requiring medication use [25]. Compared with no diabetes during pregnancy, an increased risk of childhood asthma was reported only in GDM cases requiring antidiabetic medications (HR: $1.12,95 \% \mathrm{Cl}$ : 1.01-1.25) but not in those without requiring medications. These findings were independent of maternal asthma. The Boston Birth cohort found that GDM, independently of maternal pregnancy BMI and foetal growth, was associated with atopic dermatitis and allergen sensitization (driven primarily by food sensitization) in term births but not preterm, with speculation that term births had longer exposure to the hyperglycaemic insult at a specific point of immunological development [26]. A meta-analysis did not find an association of maternal diabetes (defined as either chronic diabetes before pregnancy or overt diabetes or glucose intolerance in pregnancy) with ever and recurrent wheezing in early childhood from birth up to 1-2 years of age [27].

Although the immune system is a complex network affected by various environmental and genetic factors, the potential role of the human microbiota in influencing the host immune system has drawn considerable attention. It has been proposed that GDM triggers gut microbiota dysbiosis (i.e., altered gut microbial ecosystem) in both the mother and neonate [28], which could lead to alteration of T-cell subpopulations, in turn implicated in maintaining immune tolerance. Indeed, mothers with GDM exhibited higher levels of peripheral Th2, Th17, and regulatory T cells, with these remaining unchanged from the third trimester of pregnancy up to 6 months post-partum [29]. Hence, it is plausible that altered levels of $T$ cells in the mother have an epigenetic impact on the immunological function of the offspring.

\section{Offspring Neurocognitive Development and Behavioural Outcomes}

While more is known about the association between maternal diabetes (regardless of the type) and offspring neurodevelopmental outcomes, evidence on the adverse effect of GDM is currently inconclusive. A systematic review reported that while overall intellectual function may be within the normal range in children born to mothers with GDM, they may have an increased risk for problems related to fine and gross motor coordination, attention span, and activity level compared to children born to mothers without GDM [30]. A number of important confounding factors, such as socioeconomic status, parental educational level, and family upbringing, contribute to children's cognitive performance [31]. Table 3 summarizes selected cohort studies and meta-analyses that have examined the association of GDM and offspring neurodevelopmental outcomes. In a meta-analysis adjusting for parental educational attainment, a deleterious effect of maternal dia- 
Table 3. Selected studies linking GDM with neurodevelopmental outcomes

\begin{tabular}{|c|c|c|c|c|c|c|}
\hline Study & Design & Cohort & $\begin{array}{l}\text { Sample } \\
\text { size }\end{array}$ & GDM criteria & Offspring age, years & $\begin{array}{l}\text { Major outcomes for GDM-exposed } \\
\text { offspring }\end{array}$ \\
\hline $\begin{array}{l}\text { Kong } \\
\text { et al. [36], } \\
\text { Sweden }\end{array}$ & Cohort & $\begin{array}{l}\text { Data linkage of Finland's } \\
\text { nationwide registers }\end{array}$ & 649,043 & Medical record & From birth to 11 & $\begin{array}{l}\text { GDM + maternal obesity associated with } \\
\text { autism spectrum disorders (HR: } 1.56 \text {, } \\
95 \% \text { CI: } 1.26-1.93 \text { ) } \\
\text { Non-significant increase in GDM + } \\
\text { normal weight for autism, adjusted for } \\
\text { maternal psychiatric disorder, maternal } \\
\text { age at delivery, maternal smoking, and } \\
\text { maternal systemic inflammatory disease }\end{array}$ \\
\hline $\begin{array}{l}\text { Nahum } \\
\text { Sacks } \\
\text { et al. [38], } \\
\text { Israel }\end{array}$ & Cohort & $\begin{array}{l}\text { A university medical } \\
\text { centre which serves the } \\
\text { entire population of the } \\
\text { southern region of } \\
\text { Israel }\end{array}$ & 231,271 & Medical record & $\begin{array}{l}\text { Not specified (study population } \\
\text { included all patients who } \\
\text { delivered between the years } \\
1991 \text { through } 2014 \text { and their } \\
\text { offspring) }\end{array}$ & $\begin{array}{l}\text { Associated with autistic spectrum } \\
\text { disorder (OR: } 4.44 ; 95 \% \mathrm{Cl}: 1.55-12.69 \text { ), } \\
\text { adjusted for maternal age, obesity, } \\
\text { gestational week }\end{array}$ \\
\hline $\begin{array}{l}\text { Wan } \\
\text { et al. [35], } \\
\text { China }\end{array}$ & $\begin{array}{l}\text { Meta- } \\
\text { analysis }\end{array}$ & $\begin{array}{l}\text { Included } 16 \text { case- } \\
\text { control/cohort studies; } \\
\text { USA, Canada, Sweden, } \\
\text { Israel, Australia, Egypt }\end{array}$ & $\begin{array}{l}\text { Not } \\
\text { specified }\end{array}$ & $\begin{array}{l}\text { Exposure: maternal } \\
\text { diabetes }\end{array}$ & Not specified & $\begin{array}{l}\text { Associated with autism spectrum } \\
\text { disorders (relative risk: } 1.48 ; 95 \% \mathrm{Cl} \text { : } \\
1.26-1.75 \text { ), adjusted for obesity, maternal } \\
\text { age, gestational age }\end{array}$ \\
\hline $\begin{array}{l}\text { Xiang } \\
\text { et al. [34], } \\
\text { USA }\end{array}$ & Cohort & $\begin{array}{l}\text { Kaiser Permanente } \\
\text { Southern California } \\
\text { hospitals (retrospective } \\
\text { birth cohort) }\end{array}$ & 29,534 & Carpenter-Coustan & Median age: 4.9 & $\begin{array}{l}\text { GDM requiring antidiabetic medications } \\
\text { associated with ADHD (HR: } 1.26,95 \% \mathrm{Cl} \text { : } \\
\text { 1.14-1.41) } \\
\text { No association for GDM not requiring } \\
\text { medications }\end{array}$ \\
\hline $\begin{array}{l}\text { Zhao } \\
\text { et al. [33], } \\
\text { China }\end{array}$ & $\begin{array}{l}\text { Meta- } \\
\text { analysis }\end{array}$ & $\begin{array}{l}\text { Included } 4 \text { cohort } \\
\text { studies; Denmark, } \\
\text { Greece, USA, China }\end{array}$ & 985,984 & $\begin{array}{l}\text { Medical record, } \\
\text { self-report, ADA } \\
\text { criteria }\end{array}$ & Range: 4-19 & $\begin{array}{l}\text { Associated with ADHD (RR: } 2.00,95 \% \mathrm{Cl} \text { : } \\
1.42-2.81 \text { ) }\end{array}$ \\
\hline
\end{tabular}

ADHD, attention deficit hyperactivity disorder; $\mathrm{Cl}$, confidence interval; GDM, gestational diabetes mellitus; IQ, intelligence quotient; HR, hazard ratio; OR, odds ratio; RR, risk ratio; SMD, standardized mean difference.

betes (encompassing GDM and type 1 and type 2 diabetes) on lower IQ score was observed in children aged 3-12 years, but the authors cautioned against drawing conclusions due to significant heterogeneity in included studies [32]. It is plausible that women with pre-existing diabetes may have received monitoring and counselling prior to pregnancy and therefore have better controlled glucose levels. Offspring born to mothers with GDM may have a higher exposure to a greater level of circulating glucose during the early stages of pregnancy than those with pre-existing diagnosed diabetes.

An increased risk for attention deficit hyperactivity disorder (ADHD) in children born to mothers with GDM (risk ratio: 2.00, 95\% Cl: 1.42-2.81, 985,984 children) has been shown in a meta-analysis [33]. Notably, a large-sample US study suggests that severe GDM requiring antidiabetic medications was associated with increased ADHD risk (HR: 1.26, 95\% Cl: 1.141.41) in children (median age: 4.9 years) compared to the non- exposed group [34]. Neither GDM requiring no medications nor gestational age at GDM diagnosis was associated with offspring ADHD risk. These associations were independent of sociodemographic factors, smoking and alcohol use, maternal history of ADHD, and maternal pre-pregnancy BMI.

There are a number of observational epidemiologic studies published on offspring autism spectrum disorder outcome. A meta-analysis detected a positive association between GDM and child autism spectrum disorders even after adjustment for important covariates such as obesity, maternal age, and gestational age [35]. However, a Finnish cohort of 649,043 births followed up to 11 years reported no increased risk of child's autism spectrum disorders in women with GDM and normal weight, after adjusting for important covariates including maternal psychiatric disorder, maternal age at delivery, maternal smoking, and maternal systemic inflammatory disease [36]. Of note, more-pronounced risk effects for child autism spec- 
trum disorders were reported in obese mothers with GDM and/or maternal pre-gestational diabetes [36, 37]. Joint effects of maternal obesity and pre-gestational diabetes were also observed on conduct disorders with onset in childhood as well as mixed disorders of conduct and emotions, disorders of social functioning, and tic disorders with onset in childhood and adolescence [36]. Possible explanations for the joint effects between obesity and maternal pre-gestational diabetes are the stronger neural impact of long-term exposure to concomitant contribution of lipotoxicity, inflammation, metabolic stress, and hyperglycaemia. Limited data exist regarding other offspring neuropsychiatric disorders, with some showing either higher rates [38] or null associations [36] with eating disorders and positive associations of sleep disorders [36, 38] in children exposed to GDM.

\section{Developmental Programming by Epigenetic Mechanisms}

In the context of foetal programming, epigenetic processes are thought to be an important mechanism underpinning lasting effects on the offspring [9]. Epigenetic modifications are cell type and tissue specific, which involve changes in gene expression and genomic structure without altering the DNA sequence. Epigenetic processes include DNA methylation, histone post-translational modifications, and expression of non-coding RNAs. GDM, as an example of maternal environmental trigger, can play a role in influencing offspring outcomes through epigenetic regulation of genes. DNA methylation is the classic and most studied epigenetic measure, primarily found in the CpG (cytosine followed by a guanine) sequence contexts. The identification of DNA methylation patterns related to adverse health-related outcomes in offspring is a potentially useful tool to assess individuals at risk for health problems in early life exposed to GDM, representing an important window of opportunity for early interventions during childhood.

\section{Animal Studies}

Evidence from non-human animal models suggests that in utero GDM exposure leads, for example, to developmental and functional alterations of the hypothalamus [6, 39], heightening the risk of developing overweight/obesity in the offspring. Animal models of developmental programming have to date mainly involved nutritional, toxin exposure, selective breeding, and direct genetic manipulations.
A study of streptozotocin-induced maternal diabetes in mice showed an inhibitory effect of intrauterine hyperglycaemia exposure on the development of brown adipose tissue (BAT) in offspring, thereby impairing the glucose uptake function of BAT in adulthood [40]. The authors found a downregulation of BAT-associated genes, Ucp1, Cox5b, and Elovl3, which is accompanied by disorganized ultra-structure of mitochondria in BAT, probably contributing to intracellular lipid accumulation and fat-induced insulin resistance [40]. Another GDM mouse model showed altered DNA methylation patterns in pancreatic tissues, manifested as dyslipidaemia, impaired glucose tolerance, and insulin resistance with advancing age [41]. The authors rationalized that the pancreas has a direct role in regulating blood glucose levels and should hence serve as an important target tissue to demonstrate the role of DNA methylation as opposed to the more widely studied samples such as the placenta, umbilical cord blood, or maternal peripheral blood.

However, animal models using chemical approaches such as streptozotocin to induce permanent pancreatic damage with impaired insulin secreting function and irreversible diabetes may be of limited relevance to GDM, which is transient in nature and usually returns to euglycaemia after childbirth. A recent mice experiment studied the induction of transient glucose tolerance in pregnant mice with an insulin receptor antagonist (S961), reporting that mice born from S961-treated dams showed no susceptibility to physical or reflexes development in the early neonatal period but had long-term metabolic (glucose intolerance) and cognitive impairment consequences in adulthood when administered a high-fat diet [42]. The administration of high-fat diets in mice mimics typical energy-rich diets in both developing and industrialized countries, implicating epigenetic alterations as an important mechanism underpinning the induction of altered phenotypes in response to environmental cues.

\section{Human Studies}

The mechanistic pathways underlying long-term morbidity in offspring exposed to GDM are incompletely understood so far, but a growing number of studies have supported involvement of epigenetic mechanisms in the association of GDM with offspring health. Most human studies on epigenetic mediation examined the associations of in utero GDM exposure and DNA methylation in placentas, offspring cord, or infant blood, as summarized in a recent review [43]. Several differentially methylated genes in foetal tissues of babies born to mothers with GDM have been identified using a candidate gene approach; these include loci related to the leptin ( $L E P)$, 
adiponectin (ADIPOQ), mesoderm-specific transcript (Mest), ATP-binding cassette transporter A1 (ABCA1), SLC2A1/GLUT1, and SLC2A3/GLUT3 genes. Epigenetic modifications at these loci in response to impaired glucose homeostasis during pregnancy might lead to lifelong susceptibility to adiposity development in offspring.

Two epigenome-wide association studies (EWAS) using IIlumina 450k methylation arrays have reported associations of maternal diabetes-related DNA methylation marks with childhood adiposity-related outcomes $[44,45]$. One of these studies included data from 2 prospective cohorts - the EPOCH (Exploring Perinatal Outcomes in Children) and the Colorado Healthy Start - which identified 6 GDM exposure-associated DNA methylation marks that were linked to measures of childhood adiposity and fat distribution [44]. Peripheral/cord blood samples of GDM-exposed and non-GDM-exposed offspring ( $n=285$, aged 10.5 years) were profiled, revealing that DNA methylation of the SH3PXD2A gene was associated with BMI, waist circumference, skinfold thicknesses, subcutaneous adipose tissue, and leptin levels, after adjustment for cell proportions [44]. In the second study of 388 Pima Indian children of Arizona (aged 13.0 years) [45], the observed DNA methylation marks altered by intrauterine exposure to maternal diabetes and linked to offspring BMI and insulin secretory were different from those detected by the EPOCH study. The discrepancies in DNA methylation hits could be due to the different population studied, covariates adjusted for, and outcomes of interest.

A causal relation between maternal hyperglycaemia and epigenetic regulation of the leptin gene (with biological relevance to long-term programming of offspring excessive adiposity) in offspring cord blood has been reported based on a 2-step epigenetic Mendelian randomized approach [46]. The epigenetic adaptations triggered by maternal glycaemia resulted in an association between lower DNA methylation levels at the CpG site cg12083122 (in the leptin gene of the offspring) and higher cord blood leptin levels [46]. Using mediation analysis, higher DNA methylation levels of the key genes responsible for glycaemic/lipid metabolism (PPARGC1 $\alpha$ ) were found to be correlated with higher cord blood leptin levels in offspring exposed to maternal hyperglycaemia [47]. DNA methylation (increased methylation of PYGO1 and CLN8) has also been reported to mediate effects of in utero GDM exposure on adverse offspring cardiometabolic traits (increased VCAM-1 levels) [48].

For neurodevelopmental outcome, a recent meta-analysis of EWAS data published by the Pregnancy and Childhood Epigenetics Consortium (with 3,677 mother-neonate pairs from 7 pregnancy cohorts) showed that GDM was associated with offspring cord blood hypomethylation of the OR2L13 pro- moter, a gene associated with autism spectrum disorder [49]. Notably, the study accounted for numerous potential confounding influences, including cord blood cell heterogeneity, which is one of the potential sources of variability in DNA methylation.

In a human placenta study [50], maternal dysglycaemia in pregnancy was associated with altered DNA methylation of the serotonin transporter gene (SLC6A4), a principal regulator of serotonin homeostasis. Serotonin, a neurotransmitter, is involved in neurodevelopmental disorders (e.g., depression, anxiety, and autism). SLC6A4 methylation levels were negatively associated with maternal glucose levels (both fasting and 2-h plasma glucose) in the 24-28 weeks of gestation, after adjustment for maternal pre-pregnancy BMI and gestational weight gain. Further, placental SLC6A4 methylation was inversely associated with SLC6A4 mRNA levels, suggesting a functional role of the CpG sites in regulating SLC6A4 gene expression and that epigenetic changes predominate over genetic mechanism in the human placenta. A separate study has shown differential SLC6A4 methylation as a predictive epigenetic marker of adiposity from birth to adulthood [51]. Such studies provide valuable information on epigenetic marks that can guide future research in developing potential diagnostic biomarkers and predictive/treatment strategies for adverse health events.

\section{Transgenerational Epigenetic Inheritance}

Increasing research on animal models, mainly in mice and rats, suggests that developmental programming is a transgenerational phenomenon. The programmed phenotype is passed on through several possible mechanisms including persistence of the adverse environmental exposures in subsequent generations, altered maternal phenotype, and inheritance of epigenetic modifications via alteration of the epigenome (germline and/or somatic line). Whilst most literature on transgenerational transmission of traits have focused on the maternal contributions to offspring, impacts of paternal contributions have also been observed [4].

A GDM mice model of intrauterine hyperglycaemia induced by streptozotocin showed a pattern of dysregulation at key methylation sites in the placenta (reflected by downregulation and upregulation of DIk1 and Gtl2 genes, respectively) of the F1 and F2 generations [52]. A reduction in placental weight was found to be transmitted paternally to the F2 offspring, but not maternally, which was believed to be linked to the susceptibility of the sperm under a suboptimal intrauterine environment. 
While the transgenerational transmission of traits has been reported through to the F2 offspring, evidence on the transmission through to $\mathrm{F} 3$ and subsequent generations remains unclear [53]. Studying F3 and succeeding generations is important to eliminate the possible confounding effects by the initial adverse maternal insults on the embryo.

Although there is substantial evidence on the transgenerational inheritance of epigenetic modifications in mice and rats, the application of this concept in humans has been challenged by others [54], mainly due to a complex sum of many confounding factors including ecological and cultural inheritance [55]. Well-controlled experiments in mammalian animal models and large-scale cohorts/well-characterized epidemiological studies are required in the future.

\section{Do GDM Treatment Interventions Improve Long-Term Offspring Health?}

Infants born to mothers receiving treatment of GDM in the form of dietary advice, blood glucose monitoring, and insulin therapy have improved perinatal outcomes compared with those born to women receiving routine care [56]. However, evidence from a Cochrane review of long-term follow-up studies of GDM treatment interventions suggests that treatment may not reduce childhood obesity [13]. In 2 follow-up studies of children whose mothers participated in pregnancy trials for the treatment of mild GDM, there was no difference in child's BMI (aged 4-10 years) by treatment and control groups [57, 58]. A possible reason for the null finding is that more-pronounced GDM might be necessary to program long-term treatment effects on the development of offspring obesity. Nonetheless, female offspring of mothers treated for mild GDM had lower fasting glucose levels, suggesting a beneficial effect of treatment of mild GDM in relation to reducing the risk of offspring insulin resistance in females [57].

Compared with insulin treatment, findings from the Metformin in Gestational diabetes: The Offspring Follow-Up (MiG TOFU) cohort reported no differences in the body fat percent and metabolic measures in children (aged 7-9 years) whose mothers had been randomized to metformin and insulin GDM treatment [59]. However, metformin-exposed children at 9 years of age were larger than the insulin-exposed group [59]. In line with this, a meta-analysis including 3 follow-up studies of RCTs reported that children prenatally exposed to metformin treatment for GDM were heavier than those whose mothers received insulin treatment [60]. Larger studies with longer follow-up will be needed to better understand the health impact of GDM treatments on offspring to optimize the health of future generations.

There is also evidence for the periconceptional period as an early window for which poor environmental exposures can induce adverse health effects in offspring [4]. Interventions delivered during pregnancy may only partly alter foetal growth and development, and therefore studies examining interventions that begin before conception are warranted. A large multi-centre RCT is underway to investigate the effectiveness of a nutritional (containing myoinositol, probiotics, and additional micronutrients) intervention commencing before conception and continuing during pregnancy to maintain good maternal glycaemic control, with the aim of improving offspring health outcomes [61].

\section{Conclusion}

Overall, there is increasing evidence for an impact of in utero GDM exposure on lifetime health in the offspring. However, whether maternal GDM contributes directly to childhood adiposity remains to be elucidated, given that maternal BMI and gestational weight gain are also linked with childhood adiposity. Other observed long-term offspring adverse consequences include cardiovascular abnormalities, glucose/insulin dysfunction, allergic/respiratory health, and neurodevelopmental outcomes. Most evidence is based on observational prospective cohorts, and further studies are required to advance our knowledge of the effect of GDM and its treatment on development, function, and health in the offspring. Taken together, the adverse health impacts of in utero GDM exposure on offspring may rely upon epigenetic changes in selected genes. Notably, many of these epigenetic modifications may not be reversible and may persist throughout the offspring's life course. More studies in both animal and human models 
are needed to replicate the epigenetic findings, with careful consideration of the selection of cell or tissue types for epigenetic analysis because epigenetic mechanisms are generally tissue specific. There is also a need for larger studies with long-term follow-up to understand the health impact of GDM treatments in preventing adverse programming of health outcomes in offspring.

\section{Conflict of Interest Statement}

K.M.G. has received reimbursement for speaking at conferences sponsored by companies selling nutritional products and is part of an academic consortium that has received research funding from Abbott Nutrition, Nestec, BenevolentAl Bio Ltd., and Danone. K.M.G. is supported by the UK Medical Research Council (MC_UU_12011/4), the National Institute for Health Research (NIHR Senior Investigator [NFSI-0515-10042] and NIHR Southampton Biomedical Research Centre [IS-BRC-1215-20004]), the European Union (Erasmus + Project ImpENSA 598488-EPP-1-2018-1-DE-EPPKA2-CBHE-JP), the British Heart Foundation (RG/15/17/3174), and the US National Institute On Aging of the National Institutes of Health (Award No. U24AG047867). The writing of this article was supported by Nestle Nutrition Institute and the authors declare no other conflicts of interest.

\section{References}

1 American Diabetes Association. 2. Classification and diagnosis of diabetes. Diabetes Care. 2016 Dec;40(Suppl 1):S11-24.

2 International Diabetes Federation. IDF diabetes atlas. 9th ed. Brussels, Belgium: International Diabetes Federation; 2019.

3 Landon MB, Spong CY, Thom E, Carpenter MW, Ramin SM, Casey $B$, et al. A multicenter, randomized trial of treatment for mild gestational diabetes. N Engl J Med. 2009;361(14):1339-48.

4 Fleming TP, Watkins AJ, Velazquez MA, Mathers JC, Prentice AM, Stephenson J, et al. Origins of lifetime health around the time of conception: causes and consequences. Lancet. 2018;391(10132): $1842-52$.

5 Burlina S, Dalfrà MG, Lapolla A. Short- and long-term consequences for offspring exposed to maternal diabetes: a review. J Matern Fetal Neonatal Med. 2019;32(4):687-94.

6 Steculorum SM, Bouret SG. Maternal diabetes compromises the organization of hypothalamic feeding circuits and impairs leptin sensitivity in offspring. Endocrinology. 2011;152(11):4171-9.

7 Morris MJ, Chen $\mathrm{H}$. Established maternal obesity in the rat reprograms hypothalamic appetite regulators and leptin signaling at birth. Int J Obes. 2009;33(1):115-22.

8 Pedersen J. Glucose content of the amniotic fluid in diabetic pregnancies; correlations with the maternal blood sugar. Acta Endocrinol. 1954;15(4):342-54.

9 Godfrey KM, Costello PM, Lillycrop KA. The developmental environment, epigenetic biomarkers and long-term health. J Dev Orig Health Dis. 2015;6(5):399-406.

10 Lowe WL, Scholtens DM, Lowe LP, Kuang A, Nodzenski M, Talbot $O$, et al. Association of gestational diabetes with maternal disorders of glucose metabolism and childhood adiposity. JAMA. 2018; 320(10):1005-16

11 Chen YL, Han LL, Shi XL, Su WJ, Liu W, Wang LY, et al. Adverse pregnancy outcomes on the risk of overweight offspring: a population-based retrospective study in Xiamen, China. Sci Rep. 2020;10(1):1549.

GDM and Developmental Programming
12 Kawasaki M, Arata N, Miyazaki C, Mori R, Kikuchi T, Ogawa Y, et al. Obesity and abnormal glucose tolerance in offspring of diabetic mothers: a systematic review and meta-analysis. PLoS One. 2018; 13(1):e0190676

13 Brown J, Alwan NA, West J, Brown S, Mckinlay CJ, Farrar D, et al. Lifestyle interventions for the treatment of women with gestational diabetes. Cochrane Database Syst Rev. 2017;5(5):CD011970.

14 Godfrey KM, Reynolds RM, Prescott SL, Nyirenda M, Jaddoe VW, Eriksson JG, et al. Influence of maternal obesity on the long-term health of offspring. Lancet Diabetes Endocrinol. 2017;5(1):53-64.

15 Boeke CE, Oken E, Kleinman KP, Rifas-Shiman SL, Taveras EM, Gillman MW. Correlations among adiposity measures in schoolaged children. BMC Pediatr. 2013;13:99.

16 Mooney A, Kelsey L, Fellingham GW, George JD, Hager RL, Myrer JW, et al. Assessing body composition of children and adolescents using dual-energy X-ray absorptiometry, skinfolds, and electrical impedance. Meas Phys Educ Exercise Sci. 2011;15(1):2-17.

17 Shafaeizadeh S, Harvey L, Abrahamse-Berkeveld M, Muhardi L, van der Beek EM. Gestational diabetes mellitus is associated with agespecific alterations in markers of adiposity in offspring: a narrative review. Int J Environ Res Public Health. 2020;17(9):3187.

18 Nattero-Chávez L, Luque-Ramírez M, Escobar-Morreale HF. Systemic endocrinopathies (thyroid conditions and diabetes): impact on postnatal life of the offspring. Fertil Steril. 2019;111(6):1076-91.

19 Pathirana MM, Lassi ZS, Roberts CT, Andraweera PH. Cardiovascular risk factors in offspring exposed to gestational diabetes mellitus in utero: systematic review and meta-analysis. J Dev Orig Health Dis. 2020;6:1-18.

20 Blotsky AL, Rahme E, Dahhou M, Nakhla M, Dasgupta K. Gestational diabetes associated with incident diabetes in childhood and youth: a retrospective cohort study. CMAJ. 2019;191(15):E410-7.

21 Lowe WL Jr, Scholtens DM, Kuang A, Linder B, Lawrence JM, Lebenthal $Y$, et al. Hyperglycemia and Adverse Pregnancy Outcome Follow-Up Study (HAPO FUS): maternal gestational diabetes mellitus and childhood glucose metabolism. Diabetes Care. 2019;42(3):372-80. 
22 Yu Y, Arah OA, Liew Z, Cnattingius S, Olsen J, Sørensen HT, et al. Maternal diabetes during pregnancy and early onset of cardiovascular disease in offspring: population based cohort study with 40 years of follow-up. BMJ. 2019;367:16398.

$23 \varnothing y e n$ N, Diaz LJ, Leirgul E, Boyd HA, Priest J, Mathiesen ER, et al. Prepregnancy diabetes and offspring risk of congenital heart disease: a nationwide cohort study. Circulation. 2016;133(23):224353.

24 Parnell AS, Correa A, Reece EA. Pre-pregnancy obesity as a modifier of gestational diabetes and birth defects associations: a systematic review. Matern Child Health J. 2017;21(5):1105-20.

25 Martinez MP, Lin J, Chow T, Chung J, Wang X, Xiang AH. Maternal gestational diabetes and type 2 diabetes during pregnancy and risk of childhood asthma in offspring. J Pediatr. 2020;219:173-79.e1.

26 Kumar R, Ouyang F, Story RE, Pongracic JA, Hong X, Wang G, et al. Gestational diabetes, atopic dermatitis, and allergen sensitization in early childhood. J Allergy Clin Immunol. 2009;124(5): 1031-4.

27 Zugna D, Galassi C, Annesi-Maesano I, Baïz N, Barros H, Basterrechea $M$, et al. Maternal complications in pregnancy and wheezing in early childhood: a pooled analysis of 14 birth cohorts. Int J Epidemiol. 2015;44(1):199-208.

28 Wang J, Zheng J, Shi W, Du N, Xu X, Zhang Y, et al. Dysbiosis of maternal and neonatal microbiota associated with gestational diabetes mellitus. Gut. 2018;67(9):1614-25.

29 Sifnaios E, Mastorakos G, Psarra K, Panagopoulos ND, Panoulis K, Vitoratos N, et al. Gestational diabetes and T-cell (Th1/Th2/Th17/ Treg) immune profile. In Vivo. 2019 Jan-Feb;33(1):31-40.

30 Ornoy A, Reece EA, Pavlinkova G, Kappen C, Miller RK. Effect of maternal diabetes on the embryo, fetus, and children: congenital anomalies, genetic and epigenetic changes and developmental outcomes. Birth Defects Res C Embryo Today. 2015;105(1):53-72.

31 Kelstrup L, Bytoft B, Hjort L, Houshmand-Oeregaard A, Mathiesen ER, Damm P, et al. Diabetes in pregnancy: long-term complications of offsprings. Front Diabetes. 2019;28:201-22.

32 Robles MC, Campoy C, Fernandez LG, Lopez-Pedrosa JM, Rueda $\mathrm{R}$, Martin MJ. Maternal diabetes and cognitive performance in the offspring: a systematic review and meta-analysis. PLoS One. 2015; 10(11):e0142583.

33 Zhao L, Li X, Liu G, Han B, Wang J, Jiang X. The association of maternal diabetes with attention deficit and hyperactivity disorder in offspring: a meta-analysis. Neuropsychiatr Dis Treat. 2019;15: 675-84.

34 Xiang AH, Wang X, Martinez MP, Getahun D, Page KA, Buchanan TA, et al. Maternal gestational diabetes mellitus, type 1 diabetes, and type 2 diabetes during pregnancy and risk of ADHD in offspring. Diabetes Care. 2018;41(12):2502-8.

35 Wan H, Zhang C, Li H, Luan S, Liu C. Association of maternal diabetes with autism spectrum disorders in offspring: a systemic review and meta-analysis. Medicine. 2018;97(2):e9438.

36 Kong L, Norstedt G, Schalling M, Gissler M, Lavebratt C. The risk of offspring psychiatric disorders in the setting of maternal obesity and diabetes. Pediatrics. 2018 Sep;142(3):e20180776.
37 Li M, Fallin MD, Riley A, Landa R, Walker SO, Silverstein M, et al. The association of maternal obesity and diabetes with autism and other developmental disabilities. Pediatrics. 2016;137(2):e20152206.

38 Nahum Sacks K, Friger M, Shoham-Vardi I, Abokaf H, Spiegel E, Sergienko R, et al. Prenatal exposure to gestational diabetes mellitus as an independent risk factor for long-term neuropsychiatric morbidity of the offspring. Am J Obstet Gynecol. 2016;215(3):380-7.

39 Franke K, Harder T, Aerts L, Melchior K, Fahrenkrog S, Rodekamp $\mathrm{E}$, et al. "Programming" of orexigenic and anorexigenic hypothalamic neurons in offspring of treated and untreated diabetic mother rats. Brain Res. 2005:1031(2):276-83.

40 Yu DQ, Lv PP, Yan YS, Xu GX, Sadhukhan A, Dong S, et al. Intrauterine exposure to hyperglycemia retards the development of brown adipose tissue. FASEB J. 2019;33(4):5425-39.

41 Zhu Z, Chen X, Xiao Y, Wen J, Chen J, Wang K, et al. Gestational diabetes mellitus alters DNA methylation profiles in pancreas of the offspring mice. J Diabetes Complications. 2019;33(1):15-22.

42 de Sousa RAL, de Lima EV, da Silva TP, de Souza RV, Figueiredo $C P$, Passos GF, et al. Late cognitive consequences of gestational diabetes to the offspring, in a new mouse model. Mol Neurobiol. 2019;56(11):7754-64.

43 Elliott HR, Sharp GC, Relton CL, Lawlor DA. Epigenetics and gestational diabetes: a review of epigenetic epidemiology studies and their use to explore epigenetic mediation and improve prediction. Diabetologia. 2019;62(12):2171-8.

44 Yang IV, Zhang W, Davidson EJ, Fingerlin TE, Kechris K, Dabelea D. Epigenetic marks of in utero exposure to gestational diabetes and childhood adiposity outcomes: the EPOCH study. Diabet Med. 2018;35(5):612-20.

45 Chen P, Piaggi P, Traurig M, Bogardus C, Knowler WC, Baier LJ, et al. Differential methylation of genes in individuals exposed to maternal diabetes in utero. Diabetologia. 2017;60(4):645-55.

46 Allard C, Desgagné V, Patenaude J, Lacroix M, Guillemette L, Battista MC, et al. Mendelian randomization supports causality between maternal hyperglycemia and epigenetic regulation of leptin gene in newborns. Epigenetics. 2015;10(4):342-51.

47 Côté S, Gagné-Ouellet V, Guay SP, Allard C, Houde AA, Perron P, et al. PPARGC1 $\alpha$ gene DNA methylation variations in human placenta mediate the link between maternal hyperglycemia and leptin levels in newborns. Clin Epigenetics. 2016;8:72-8.

48 West NA, Kechris K, Dabelea D. Exposure to maternal diabetes in utero and DNA methylation patterns in the offspring. Immunometabolism. 2013;1:1-9.

49 Howe CG, Cox B, Fore R, Jungius J, Kvist T, Lent S, et al. Maternal gestational diabetes mellitus and newborn DNA methylation: findings from the pregnancy and childhood epigenetics consortium. Diabetes Care. 2020;43(1):98-105.

50 Blazevic S, Horvaticek M, Kesic M, Zill P, Hranilovic D, Ivanisevic M, et al. Epigenetic adaptation of the placental serotonin transporter gene (SLC6A4) to gestational diabetes mellitus. PLoS One. 2017: 12(6):e0179934

51 Lillycrop KA, Garratt ES, Garratt ES, Titcombe P, Melton PE, Murray RJS, et al. Differential SLC6A4 methylation: a predictive epigenetic marker of adiposity from birth to adulthood. Int J Obes. 2019; 43(5): 974-88
Chu/Godfrey 
52 Jiang Y, Yu YC, Ding GL, Gao Q, Chen F, Luo Q. Intrauterine hyperglycemia induces intergenerational Dlk1-Gtl2 methylation changes in mouse placenta. Oncotarget. 2018;9(32):22398-405.

53 Aiken CE, Ozanne SE. Transgenerational developmental programming. Hum Reprod Update. 2014;20(1):63-75.

54 Heard E, Martienssen RA. Transgenerational epigenetic inheritance: myths and mechanisms. Cell. 2014;157(1):95-109.

55 Horsthemke B. A critical view on transgenerational epigenetic inheritance in humans. Nat Commun. 2018:9(1):2973.

56 Crowther CA, Hiller JE, Moss JR, McPhee AJ, Jeffries WS, Robinson JS. Effect of treatment of gestational diabetes mellitus on pregnancy outcomes. N Engl J Med. 2005;352(24):2477-86.

57 Landon MB, Rice MM, Varner MW, Casey BM, Reddy UM, Wapner RJ, et al. Mild gestational diabetes mellitus and long-term child health. Diabetes Care. 2015;38(3):445-52.
58 Gillman MW, Oakey H, Baghurst PA, Volkmer RE, Robinson JS, Crowther CA. Effect of treatment of gestational diabetes mellitus on obesity in the next generation. Diabetes Care. 2010;33(5):9648.

59 Rowan JA, Rush EC, Plank LD, Lu J, Obolonkin V, Coat S, et al. Metformin in gestational diabetes: the offspring follow-up (MiG TOFU): body composition and metabolic outcomes at 7-9 years of age. BMJ Open Diabetes Res Care. 2018;6(1):e000456.

60 van Weelden W, Wekker V, de Wit L, Limpens J, ljäs H, van Wassenaer-Leemhuis AG, et al. Long-term effects of oral antidiabetic drugs during pregnancy on offspring: a systematic review and meta-analysis of follow-up studies of RCTs. Diabetes Ther. 2018;9(5): 1811-29.

61 Godfrey KM, Cutfield W, Chan SY, Baker PN, Chong YS; NiPPeR Study Group. Nutritional intervention preconception and during pregnancy to maintain healthy glucose metabolism and offspring health ("NiPPeR"): study protocol for a randomised controlled trial. Trials. 2017;18(1):131. 